\title{
組紐状細径空気圧人工筋を用いた同軸回転直動アクチュエータ
}

\author{
竹 島 啓 純* 辻 賢一郎* 高 山 俊 男*
}

\section{Co-axial Linear-Rotary Actuator with Braided McKibben Artificial Muscles}

Hirozumi Takeshima*, Kenichirou Tsuji* and Toshio Takayama*

\begin{abstract}
This paper proposes a novel 2 DOF rotary-linear actuator driven by pneumatic artificial muscles (PAMs). This simple tubular actuator comprises some PAMs that are braided, glued, and driven periodically to realize rotary and linear motions, which makes the proposed device lighter, cheaper, and easier to sterilize. The elasticity of PAMs and the pneumatic control system without electricity or magnetic power enables the actuator to safely operate not only near a human but also under a magnetic resonance imaging (MRI) environment. In light of these advantages, the proposed actuator is expected to be suitable for a laparoscopic surgical instrument. The operation principles and structure of the actuator are explained in this paper, along with the design of a prototype, which was confirmed to be able to drive a $10[\mathrm{~mm}]$ diameter laparoscopy, in linear and rotary directions.
\end{abstract}

Key Words: Soft Robotics, Pneumatic Artificial Muscle, Rotary-Linear Actuator, Laparoscopic Surgery

1. 序論

近年, ゴムなどの柔軟な材料でできたりフトロボットに注目が 集まっている．金属などの硬い材料でできた従来のロボットと 異なり,ソフトロボットは全体が柔軟であり機構的に高いコンプ ライアンス性を持つ。こうした特徽を活かして, 形状が様々に 変化する空間での動作 [1] [2] や，様々な形状の物体の把持 [3] [5] が研究されてきた。また，空圧駆動アクチュエー夕は電気を 用いず感電の心配がない。破裂の危険性があるが，機構的に覆 うことで周囲の安全性を確保でき, 破裂時にはアクチュエータ が脱力するため安全性を確保しやすい。空圧駆動ソフトロボッ トの高いコンプライアンス性と安全性を活かして人間の動きを 補助する外部筋骨格 [6] [7], 食品把持を目指したグリッパ $[8]$, 人 と安全に触れ合うロボット [9] [10] といった人間との協調動作や 繊細な物体の近くでの安全な動作への応用が模索されている. こうしたソフトロボットの特徴は医療支援ロボットにも有用で あり, 柔らかく安全な動作を活かして医療への応用が検討され てきた[11]〜[13].

また，内視鏡手術などの低侵襲な手術の普及によって患者の QoL（Quality of Life）が向上している。これらの低侵襲手術 は, 小さな切開部位から手術器具や内視鏡を挿入し手術を行う ため, 器具の操作が切開部位によって拘束される。このため, 位置, 姿勢の自由度が切開部位を原点とした回転 3 自由度と直 進 1 自由度に制限され，操作が難しくなる。 そこで器具操作を 切開部位を原点とした 4 自由度に拘束して駆動する，様々な手 術支援装置が提案されてきた。器具の位置, 姿勢を 4 自由度に

原稿受付 2018 年 9 月 4 日

*東京工業大学

*Tokyo Institute of Technology

- 本論文は新規性（要素分野）で評価されました。
拘束するために，4 自由度以上の関節を備えた機構が研究され てきた [14] [15] ほか, 同様の構造の製品（Intuitive Surgical 社 daVinci）が現場に普及し活用されている。一方で，多数の関節 は安全性を保証する難易度やコストを増加させる原因となるた め, 位置, 姿勢の拘束を機構的に実現し， 4 自由度をそれぞれ一つ のアクチュエータで制御することで機構の単純さと安全性の確 保を目指した研究がなされてきた[16] [17]. また，1 自由度を一 つのアクチュエータで制御することで器具が受ける外力が計測 しやすくなるため, 器具に加わる力情報を術者へフィードバック する研究もなされてきた $[18] 〜[20]$. さらに, 空圧アクチュエー 夕は前述のように安全性とコンプライアンス性を持つことから, 手術支援ロボットへの応用が模索されてきた [15] [17] [19]. ま た, ロボットの手先の軽量化は, 慣性を減らし位置決めや力計測 の容易化や装置の小型化に貢献する。このため, 医療用ロボッ トの手先重量低減のために, アクチュエータをロボットの根元 に配置しリンクやワイヤで先端に力を伝える試み [16] [18] [20] や，従来の金属製の空圧シリンダに比べて軽量な空気圧人工筋 を用いる試み [21] がなされてきた。

こうした，4自由度にそれぞれアクチュエータを配置した手術 支援ロボットは, 回転 3 自由度の回転中心と直進軸を切開部位 に一致させる必要がある. 単一の出力軸に対して直進駆動と回 転駆動が可能なアクチユエータが実現できれば，ほかの回転 2 自由度の配置が容易になり, 構造の単純化が期待できる。直進 と回転を同じ出力軸で出力するアクチュエータとしては, スカラ ロボットの先端関節等にねじとスプライン軸を用いて二つモー 夕で単一の軸の直進と回転を制御する機構が広く用いられてい る. また, 電磁気を用いた例として回転モータとリニアモータを 同じ軸に配置して直進と回転を独立に駆動する手法 [22] や, 永 久磁石とコイルの配置の工夫によって直進回転アクチュエータ を実現した手法 [23] [24] が提案されている．これらのアクチュ 
エー夕は出力軸にねじや磁石を取り付ける必要があり，手で用 いる通常の手術器具を直接駆動できない.ねじや磁石を取り付 けた出力軸と手術器具を直列に接続する必要があり, 全長が長 くなってほかの機器と干渉したり，慣性が増加し制御が困難に なる恐れがある．MRI（Magnetic Resonance Imaging）環境 下での手術への応用を目指した超音波直進回転モー夕 [25] [26] はピエゾ素子で進行波を発生して出力軸を摩擦で駆動するため, 出力軸に特殊な加工が必要なく, 手術器具の円筒部などを直接 駆動でき，機構の全直を短くできる．我々も単一の出力軸に対 して直進駆動と回転駆動が可能な空圧アクチュエータを提案し たが [27], この直進回転アクチュエータもチューブの膨張によっ て進行波を発生し，出力軸を摩擦で駆動する，加圧していない 初期状態では出力軸を自由に動かせるため, 手動での操作に切 り替えたり，駆動する器具を交換したりできる.

提案した直動回転アクチュエータは, 我々が研究を続けている 多重チューブ推進機構 [28] を応用したものである.多重チュー ブ推進機構は柔軟なチューブを編んで接着した管内推進機構で あり，チューブの膨張を利用して単純な構造で高いコンプライ アンス性を持った管内推進が可能である。これまでにこの機構 を応用して, 推進と回転を制御可能な管内推進機構 [29] や 2 自 由度の平面アクチュエータ [30] を発表してきた。提案した直動 回転アクチュエータは柔軟なチューブを用いて出力軸を駆動す るため, コンプライアンス性が高く, 全体が密閉されているため 滅菌も容易である。電気, 磁気を用いないため安全で MRI 環境 下でも利用が可能であり医療分野への応用が期待できる。 また, 構造が単純であり小型で軽量, 安価であるため, トロカールに埋 め込んで手術器具を駆動可能なトロカールの実現や, ディスポー サブル化も期待できる，一方で，柔軟なチューブの膨張による 伸張力を駆動力とするため, 大きな力を出そうとするとチューブ 自体が座屈してしまい発生できる力が制限されてしまう。そこ で本研究では, 駆動力として収縮力を利用する細径 McKibben 空気圧人工筋を用いることで，発生する力によるアクチュエー 夕自体の座屈を避けて, より高性能な直進回転アクチュエータ を実現したのでこれについて報告する。

本論文では，1 章で近年のソフトロボットと手術支援ロボッ トの動向について述べ，本研究の目的を明らかにした． 2 章で は，提案機構の構造について 6 本の人工筋を用いた機構を用い て説明し，一般化した任意の偶数本の人工筋で構成された機構 の動作原理を解説する． 3 章では，製作した試作機と実験装置 の構成について述べ，提案機構の動作を確認するための実験手 法を解説する．解説した実験手法によって得られた結果を 4 章 で述べ，5章で結果を考察し今後の改善点をまとめる.

\section{2. 提 案 原 理}

\section{1 機構の構造と変形についての仮定}

提案する機構は Fig. 1 に示すように偶数本の McKibben 空 気圧人工筋を編んだ円筒状の機構であり，円筒内部に挿入した 軸を直進方向と回転方向に駆動する. 人工筋は内径 $d_{\mathrm{m}}$ のシリ コーン樹脂の薄膜（図中 “Inner membrane”）の周りに編みつ けられており，人工筋が変形することで薄膜が出力軸に接触し 推進力を発生する．まず本節では，本機構を構成するのに最低 限必要な 6 本の人工筋で構成される機構を用いて構造を説明す る. Fig. 1 に示す 6 本の人工筋のうち, 3 本は右ねじ方向に配置 され（図中 $\mathrm{R}_{1}, \mathrm{R}_{2}, \mathrm{R}_{3}$ ), 残りの 3 本は左ねじ方向に配置され ている(図中 $\mathrm{L}_{1}, \mathrm{~L}_{2}, \mathrm{~L}_{3}$ ). これらの人工筋は周期的かつ対称

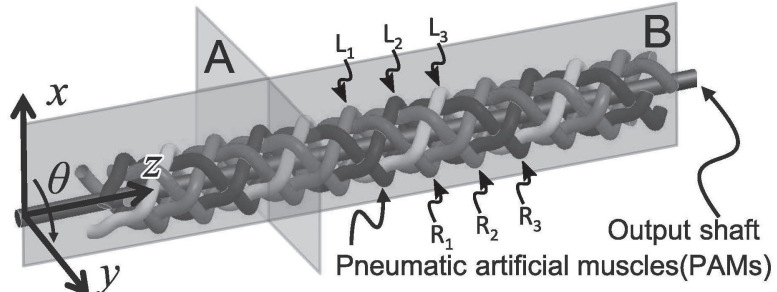

(a) Structure and the definitions of cutting planes.

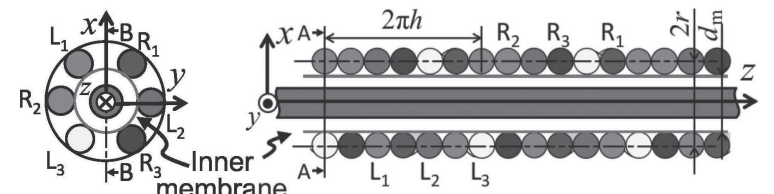

(b)

Cut-view at A-plane.

(c) Cut-view at B-plane. (Tube $\mathrm{L}_{1}, \mathrm{~L}_{2}, \mathrm{R}_{2}$, and $\mathrm{R}_{3}$ are drawn only cross-section.)

Fig. 1 Structure of a proposed linear-rotary soft actuator. $2 \pi h$ and $r$ stand for a helical pitch and radius of PAMs' central curve, respectively. $d_{\mathrm{m}}$ represents an initial inner diameter of an inner membrane

に配置されており，人工筋どうしの干渉を無視すれば人工筋の 中心座標は以下のように定式化される.ここで， $x_{\mathrm{L}_{i}}$ は Fig. 1 の $\mathrm{L}_{i}(i=1,2,3), \boldsymbol{x}_{\mathrm{R}_{i}}$ は $\mathrm{R}_{i}(i=1,2,3)$ の人工筋の中心座 標であり, $r$ はらせん曲線の半径, $2 \pi h$ はピッチである.

$$
\begin{aligned}
\boldsymbol{x}_{\mathrm{L}_{i}} & =\left(\begin{array}{c}
r \cos \left(\theta+\frac{2 \pi i}{3}\right) \\
r \sin \left(\theta+\frac{2 \pi i}{3}\right) \\
h \theta
\end{array}\right)=\boldsymbol{R}_{z}\left(\theta+\frac{2 \pi i}{3}\right) \boldsymbol{u}(\theta) \\
\boldsymbol{x}_{\mathrm{R}_{i}} & =\left(\begin{array}{c}
r \cos \left(-\theta-\frac{2 \pi i}{3}\right) \\
r \sin \left(-\theta-\frac{2 \pi i}{3}\right) \\
h \theta
\end{array}\right)=\boldsymbol{R}_{z}^{-1}\left(\theta+\frac{2 \pi i}{3}\right) \boldsymbol{u}(\theta)
\end{aligned}
$$

ただし， $\boldsymbol{R}_{z}, \boldsymbol{u}$ は以下のように定義される回転行列とべクトル である.

$$
\boldsymbol{R}_{z}(\theta)=\left(\begin{array}{ccc}
\cos \theta & -\sin \theta & 0 \\
\sin \theta & \cos \theta & 0 \\
0 & 0 & 1
\end{array}\right), \boldsymbol{u}(\theta)=\left(\begin{array}{c}
r \\
0 \\
h \theta
\end{array}\right)
$$

人工筋は加圧すると，太く短くなるように変形する，このた め Fig. 2 (a) に示すように，人工筋 $\mathrm{L}_{1}$ を加圧すると $\mathrm{L}_{1}$ が出 力軸に接触するように変形する. $\mathrm{L}_{1}$ の変形によって, 機構に屈 曲が生じるため, Fig. 2 に示した機構内の空洞の中心曲線（図 中 “Central curve”）はらせん形状に変形する。このとき，変 形後は変形した人工筋が出力軸に接触するため, 機構の中心曲 線の描く曲線の位相や向きは加圧された人工筋と等しくなると 仮定する. 同様に Fig. 2 (b) に示すように, 人工筋を複数本 (図 では $\mathrm{R}_{1}$ と $\mathrm{L}_{1}$ ) 加圧したときも加圧された人工筋が出力軸に 接するように変形し，これに伴って機構全体が屈曲する．複数 の人工筋を加圧するとき, 同じ圧力で加圧されることから, 複 数の人工筋による合力は, 人工筋の平均形状を持った人工筋に よる収縮力と等価であると考えられる. よって, 前述の機構中 心線が描く曲線が加圧された人工筋の形状と等しくなる仮定よ り, 加圧した人工筋の平均形状を求めることで変形した機構中 心線の形状を予測することができる．例えば，Fig. 2 (b) ではね じり方向の異なる 2 本の人工筋が加圧されているため, $Y$ 軸方 向の変形が打ち消され $X$ 軸方向の変形が残ることで, 機構の中 


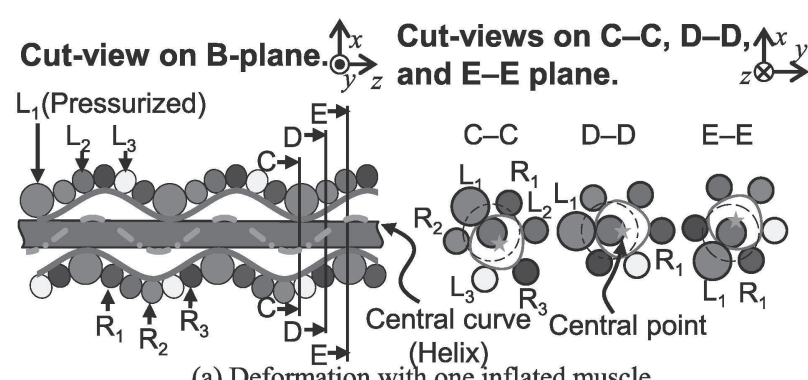

(a) Deformation with one inflated muscle.

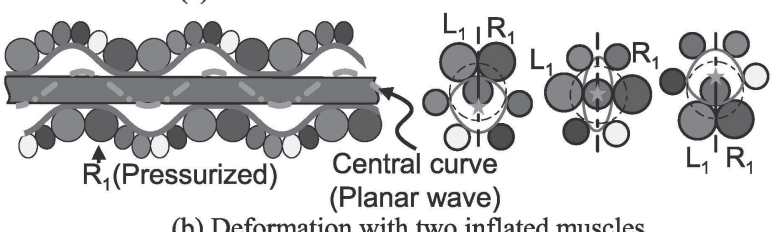

(b) Deformation with two inflated muscles.

Fig. 2 Deformation of a proposed device

心曲線が平面波を描くと予測される.

また，今後の節では機構を構成する人工筋の本数を一般化す る. 式 (1) に示した 6 本の人工筋からなる機構の人工筋中心座 標を一般化すれば， $N$ 本の右ねじりの人工筋と $N$ 本の左ねじ りの人工筋からなる $2 N$ 本編み機構は以下のように表せる。

$$
\begin{gathered}
\boldsymbol{x}_{\mathrm{L}_{i}}=\boldsymbol{R}_{z}(\theta+2 \pi i / N) \boldsymbol{u}(\theta) \\
\boldsymbol{x}_{\mathrm{R}_{i}}=\boldsymbol{R}_{z}^{-1}(\theta+2 \pi i / N) \boldsymbol{u}(\theta)
\end{gathered}
$$

ここで， $i$ は 1 以上 $N$ 以下の整数としたが，定義の周期性より 以下の関係を満たすため今後一般の整数として取り扱う.

$$
i \equiv j \quad \bmod N \Rightarrow \boldsymbol{x}_{\mathrm{L}_{i}}=\boldsymbol{x}_{\mathrm{L}_{j}} \text { かつ } \boldsymbol{x}_{\mathrm{R}_{i}}=\boldsymbol{x}_{\mathrm{R}_{j}}
$$

\section{2 加圧順序}

提案機構は各人工筋を順番に加圧, 減圧することで動作する. 加圧の順序は無数に存在するが，本論文では左右のねじれ方向 の人工筋が対称に 2 本または 4 本，加圧される順序を考える. このとき，新たに人工筋を加圧する際には，動作が滑らかにな るためにすでに加圧された人工筋と隣り合った人工筋を加圧す る必要がある.すなわち, 右ねじりの人工筋 $N$ 本のうち $i$ 番 めの人工筋 $\mathrm{R}_{i}$ と左ねじりの $j$ 番めの人工筋 $\mathrm{L}_{j}$ が加圧されて いるとき，新たに加圧される人工筋は $i \pm 1$ 番めの右ねじりの 人工筋 $\mathrm{R}_{i \pm 1}$ と $j \pm 1$ 番目の左ねじりの人工筋 $\mathrm{L}_{j \pm 1}$ である. $\mathrm{R}_{i}$ と $\mathrm{L}_{j}$ が加圧された状態を $\left(\mathrm{R}_{i}, \mathrm{~L}_{j}\right)$ と表せば，新たに 2 本 の人工筋を加圧する状態変化は以下の 4 とおりのうちいずれか である.

$$
\left(\mathrm{R}_{i}, \mathrm{~L}_{j}\right) \rightarrow\left(\mathrm{R}_{i}, \mathrm{~L}_{j}, \mathrm{R}_{i \pm 1}, \mathrm{~L}_{j \pm 1}\right) \quad \text { (複号任意) }
$$

上式の 4 とおりの状態変化を，新たに加圧する人工筋の添え字 の増減が等しい場合と異なる場合に分けた以下の場合分けで議 論する．また，今後は明記しない場合には複号同順とする.

$$
\left\{\begin{array}{l}
\left(\mathrm{R}_{i}, \mathrm{~L}_{j}\right) \rightarrow\left(\mathrm{R}_{i}, \mathrm{~L}_{j}, \mathrm{R}_{i \pm 1}, \mathrm{~L}_{j \pm 1}\right) \\
\left(\mathrm{R}_{i}, \mathrm{~L}_{j}\right) \rightarrow\left(\mathrm{R}_{i}, \mathrm{~L}_{j}, \mathrm{R}_{i \pm 1}, \mathrm{~L}_{j \mp 1}\right)
\end{array}\right.
$$

2.2 .1 左右にねじれた人工筋を等しい順序で加圧する場合 左右のねじれ方向の人工筋を等しい順序で加圧する以下の 2 とおりの加圧順序を考える.

$$
\left(\mathrm{R}_{i}, \mathrm{~L}_{j}\right) \rightarrow\left(\mathrm{R}_{i}, \mathrm{~L}_{j}, \mathrm{R}_{i \pm 1}, \mathrm{~L}_{j \pm 1}\right) \rightarrow\left(\mathrm{R}_{i \pm 1}, \mathrm{~L}_{j \pm 1}\right)
$$

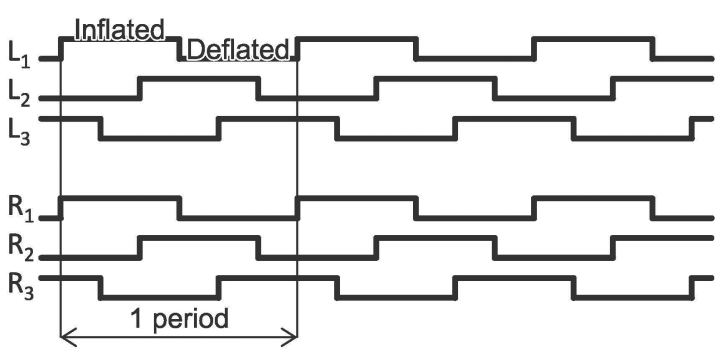

(a) Pressurizing pattern.

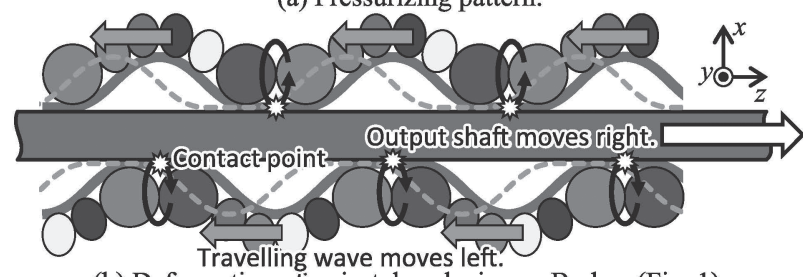

(b) Deformation of a six-tubes device on B plane(Fig. 1).

Fig. 3 Deformation that generates a planar traveling wave

2.1 節での仮定から, 各加圧状態における機構の中心曲線の変形 形状は各加圧された人工筋の形状の平均と等しくなるため, 各 加圧状態での機構中心曲線形状が以下のように導出される.

$$
\begin{aligned}
& \frac{\boldsymbol{x}_{\mathrm{R}_{i}}+\boldsymbol{x}_{\mathrm{L}_{j}}}{2}=\frac{\boldsymbol{R}_{z}\left(\theta+2 \pi \frac{i}{N}\right)+\boldsymbol{R}_{z}^{-1}\left(\theta+2 \pi \frac{i}{N}\right)}{2} \boldsymbol{u}(\theta) \\
& =\boldsymbol{R}_{z}\left(\pi \frac{i-j}{N}\right)\left(r \cos \left(\theta+\pi \frac{i+j}{N}\right) \quad 0 \quad h \theta\right)^{\tau} \\
& \left(\boldsymbol{x}_{\mathrm{R}_{i}}+\boldsymbol{x}_{\mathrm{L}_{j}}+\boldsymbol{x}_{\mathrm{R}_{i \pm 1}}+\boldsymbol{x}_{\mathrm{L}_{j \pm 1}}\right) / 4 \\
& =\boldsymbol{R}_{z}\left(\pi \frac{i-j}{N}\right)\left(\begin{array}{c}
r \cos \frac{\pi}{N} \cos \left(\theta+\pi \frac{i+j \pm 1}{N}\right) \\
0 \\
h \theta
\end{array}\right) \\
& \left(\boldsymbol{x}_{\mathrm{R}_{i \pm 1}}+\boldsymbol{x}_{\mathrm{L}_{j \pm 1}}\right) / 2 \\
& =\boldsymbol{R}_{z}\left(\pi \frac{i-j}{N}\right)\left(\begin{array}{lll}
r \cos \left(\theta+\pi \frac{i+j \pm 2}{N}\right) & 0 & h \theta
\end{array}\right)^{\tau}
\end{aligned}
$$

よって, 機構は $X Z$ 平面を $Z$ 軸回りに $(i-j) \pi / N[\mathrm{rad}]$ 回転 させた平面上で平面波を描く。導出された形状より, 各状態で 平面波の位相は $(i+j) \pi / N[\mathrm{rad}] \rightarrow(i+j \pm 1) \pi / N[\mathrm{rad}] \rightarrow$ $(i+j \pm 2) \pi / N[\mathrm{rad}]$ と変化する. よって, 式（6）に示す順序 で加圧する人工筋を切り替えれば，機構が同一平面上で進行波 を描くように変形する.

この加圧順序で機構を加圧する一例として，6 本の人工筋を 備えた機構を Fig. 3 (a) の順序で加圧する例を考える.この加 圧順序では加圧される右ねじりの人工筋の番号 $i$ と左ねじりの 人工筋の番号 $j$ について以下の式が成り立つ.

$$
i-j=0, \quad i+j=2 k
$$

$k$ は任意の整数であり, 加圧状態の変化の度に 1 ずつ増加する. 機構が進行波を生じる平面が常に $X Z$ 平面と $(i-j) \pi / N=$ $0[\mathrm{rad}]$ の角度をなすことから，この加圧順序で機構を加圧す ると機構は $X Z$ 平面上で進行波状に変形する。また，機構の 進行波の位相は $(i+j) \pi / N=2 \pi k / N[\mathrm{rad}]$ となるように変 化し, 頂点が $Z$ 軸負方向 (Fig. 3(b) に示した $X Z$ 平面では 左方向）に移動する．機構の内壁の任意の点はだ円軌道を描く 
ため, 機構内壁と出力軸の接触点は常に右方向に動き続け，機 構内壁は出力軸を右方向に駆動する。この例では, $\left(\mathrm{R}_{1}, \mathrm{~L}_{1}\right)$ を 初期状態として，加圧する人工筋の添え字を順番に増加させた が，逆に減少させることで逆方向の動作が発生する。すなわち， $\left(\mathrm{R}_{1}, \mathrm{~L}_{1}\right) \rightarrow\left(\mathrm{R}_{1}, \mathrm{~L}_{1}, \mathrm{R}_{3}, \mathrm{~L}_{3}\right) \rightarrow \cdots$ の順序で加圧することで, $k$ が加圧の度に 1 ずつ減少し, 出力軸は左方向に動作する.

ほかの人工筋の組み合わせにおいても， $i-j$ の值が 0 でな いため機構が進行波を生じる平面が $X Z$ 平面を $Z$ 軸回りに回 転させた平面となるが，加圧する人工筋の添え字が等しく増減 している限り同様の進行波が生じるため出力軸は直進運動する. よって，式（6）に示すように左右にねじられた人工筋を同じ順 序で加圧すれば，機構は出力軸を直進方向に駆動する.

2.2 .2 左右にねじれた人工筋を逆の順序で加圧する場合

続いて，左右にねじれた人工筋を逆の順序で加圧する以下の 2 パターンを考える.

$$
\left(\mathrm{R}_{i}, \mathrm{~L}_{j}\right) \rightarrow\left(\mathrm{R}_{i}, \mathrm{~L}_{j}, \mathrm{R}_{i \pm 1}, \mathrm{~L}_{j \mp 1}\right) \rightarrow\left(\mathrm{R}_{i \pm 1}, \mathrm{~L}_{j \mp 1}\right)
$$

2.2.1 項での議論と同様に, 各加圧状態での機構の中心曲線の変 形形状を求めるために加圧された人工筋の平均形状を計算する.

$$
\begin{aligned}
& \left(\boldsymbol{x}_{\mathrm{R}_{i}}+\boldsymbol{x}_{\mathrm{L}_{j}}\right) / 2 \\
& =\boldsymbol{R}_{z}\left(\pi \frac{i-j}{N}\right)\left(r \cos \left(\theta+\pi \frac{i+j}{N}\right) \quad 0 \quad h \theta\right)^{\tau} \\
& \left(\boldsymbol{x}_{\mathrm{R}_{i}}+\boldsymbol{x}_{\mathrm{L}_{j}}+\boldsymbol{x}_{\mathrm{R}_{i \pm 1}}+\boldsymbol{x}_{\mathrm{L}_{j \mp 1}}\right) / 4 \\
& =\boldsymbol{R}_{z}\left(\pi \frac{i-j \pm 1}{N}\right)\left(\begin{array}{c}
r \cos \frac{\pi}{N} \cos \left(\theta+\pi \frac{i+j}{N}\right) \\
0 \\
h \theta
\end{array}\right) \\
& \left(\boldsymbol{x}_{\mathrm{R}_{i \pm 1}}+\boldsymbol{x}_{\mathrm{L}_{j \mp 1}}\right) / 2 \\
& =\boldsymbol{R}_{z}\left(\pi \frac{i-j \pm 2}{N}\right)\left(\begin{array}{lll}
r \cos \left(\theta+\pi \frac{i+j}{N}\right) & 0 & h \theta
\end{array}\right)^{\tau}
\end{aligned}
$$

上式より，式（13）の順序で人工筋を加圧したとき，機構中心 曲線の形状は，位相が $(i+j) \pi / N[\mathrm{rad}]$ で一定の平面波であ

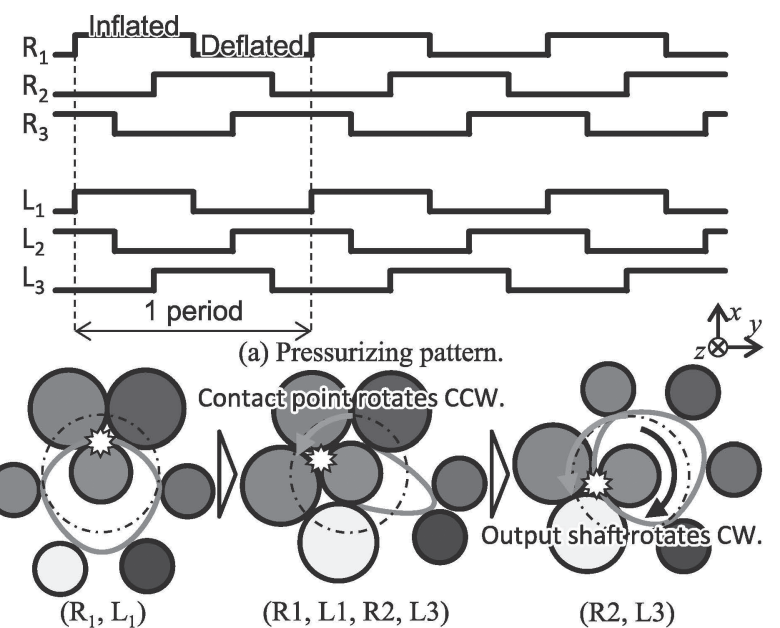

(b) Deformation of a six-muscles device on C-C plane(Fig. 2). (CW and CCW denote clockwise and counterclockwise, respectively.)

Fig. 4 Deformation that generates a rotation of a planar wave
り，平面波が生じる平面が $X Z$ 平面と $Z$ 軸回りになす角度が $(i-j) \pi / N \rightarrow(i-j \pm 1) \pi / N \rightarrow(i-j \pm 2) \pi / N[\mathrm{rad}]$ と変化 する. すなわち, 式 (13) の順序で機構を加圧すると, 機構は 一定の形状を保ちながら $Z$ 軸回りに回転するように変形する.

式 (13) の順序で 6 本の人工筋からなる機構を加圧する例と して, Fig. 4 (a) に示す加圧順序を考える.この加圧順序では, 加圧される人工筋の番号 $i, j$ が常に以下の関係を満たす.

$$
i+j \equiv 2 \quad \bmod N=3, \quad i-j=2 k
$$

前項と同様に $k$ は任意の整数であり, 加圧の度に 1 ずつ増加 する.よって，機構の描く平面波の位相は常に $(i+j) / 3 \pi=$ $2 \pi / 3[\mathrm{rad}]$ となり, 機構が正弦波を描く平面と $X Z$ 平面との角 度は $(i-j) \pi / 3=2 \pi k / 3[\mathrm{rad}]$ となるように変形する．ここで, Fig. 4 (b) に示すように $X Y$ 平面に平行な平面での断面図に着 目すれば, $k$ が増加すると, 内壁と出力軸の接点が反時計回り に回転するため出力軸が時計回りに回転し, 逆の順番で加圧し た場合には逆に回転する。よって，左右にねじられた人工筋を それぞれ逆の順番で加圧することで機構は出力軸を回転させる.

\section{3. 試作機, 実験装置}

\section{1 試作機}

提案した機構の動作を検証するために, Fig. 5 に示す試作機を 製作した。試作機は基部 (図中 “Base"), 組紐状人工筋 ("Braided muscles"), 出力軸 ("Output shaft"), 二つの出力軸スライダ ("Shaft guide"), 組紐状人工筋固定スライダ ("End slider") から構成されている. 組紐状人工筋は 12 本の人工筋で構成さ れており，6本が右ねじり $\left(\mathrm{R}_{1} \cdots \mathrm{R}_{6}\right)$, 残りの 6 本が左ねじ り $\left(\mathrm{L}_{1} \cdots \mathrm{L}_{6}\right)$ の人工筋である. 試作機は Fig. $5(\mathrm{a})$ に示した 外形 $10[\mathrm{~mm}]$ 質量 $170[\mathrm{~g}]$ の硬性内視鏡の駆動を目指して外径 $10[\mathrm{~mm}]$ の軸を駆動するように設計した。試作機には初期外径 $3[\mathrm{~mm}]$ の細径空気圧人工筋（株式会社 s-muscle SM20）をピッ チ $2 \pi h$ が $120[\mathrm{~mm}]$ になるように, 内径 $14[\mathrm{~mm}]$ 厚み $1[\mathrm{~mm}]$ のシリコーン薄膜の周りに編みつけて接着した。出力軸は 2 箇

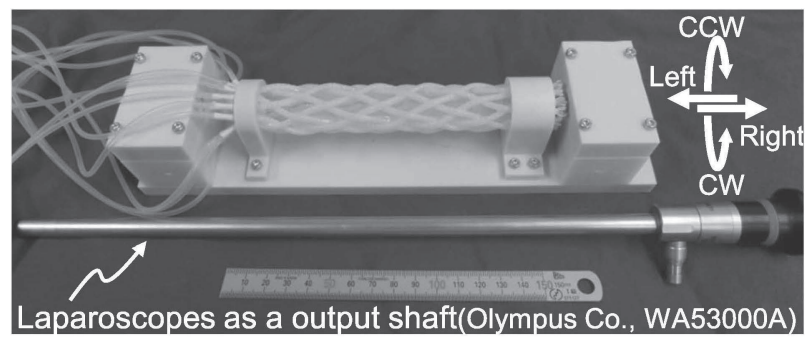

(a) Prototype and definitions of directions.

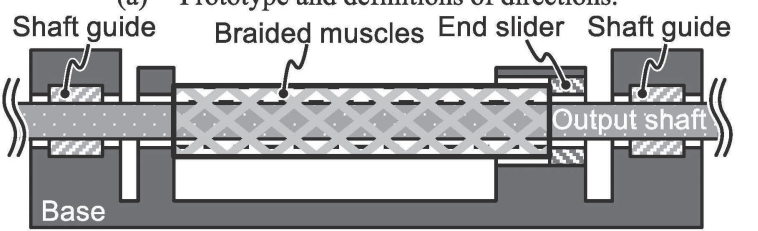

(b) Cutview of a prototype (No muscle inflates).

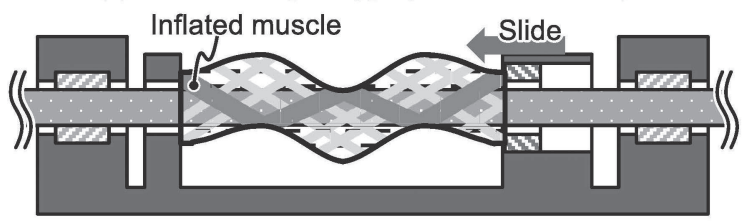

(c) Motion of the end slider when a muscles inflates.

Fig. 5 Prototype 
所の出力軸スライダによって，軸方向の直進と軸回りの回転に 運動が拘束されている. 出力軸スライダはテフロン樹脂に直径 $10[\mathrm{~mm}]$ の穴を開けた部材であり, 出力軸は少ない摩擦で移動 できる。また，組紐状人工筋は加圧した際に Fig. 5 (c) に示す ように全長が収縮するため，一端を自由に動くことのできるス ライダに固定して自由に変形できるようにした。

\section{2 実験装置, 方法}

Fig. 6 に示す実験装置を用いて試作機の性能を検証する．実 験装置は試作機, 空圧制御装置, 変位センサで構成されている. 空圧制御装置は圧力源，レギュレータ，ソレノイドバルブから なり, 圧力源から供給される空気圧をレギュレータで調整し, ソレノイドバルブをマイコンボードで制御し任意の加圧パター ンで人工筋を加圧，減圧する．実験では 2.2 節で述べた 2 種 類の加圧パターンを検証するために，左右にねじれた人工筋を 同じ順序で加圧する Fig. 7 (a) の順序と, 逆の順序で加圧する Fig. 7 (b) に示す順序で実験した。予備実験により，加圧開始後 の人工筋内圧の応答を計測し, 内圧が時定数 $40[\mathrm{~ms}]$ の一次遅 れ系ステップ応答を示すことを確認した。 人工筋を十分に加圧 するには $80[\mathrm{~ms}]$ 以上の加圧時間が必要になるため Fig. 7 に示 す加圧順序での各人工筋の加圧時間 $3 t_{\mathrm{s}}$ が $80[\mathrm{~ms}]$ 以上になる ように以下の条件下で実験した。

$$
3 t_{\mathrm{s}}>80[\mathrm{~ms}] \Rightarrow f_{\mathrm{p}}=1 / 12 t_{\mathrm{s}}<3[\mathrm{~Hz}]
$$

出力軸の動きを動画撮影し，動画を処理することで回転速度 を計測し，レーザ変位計で出力軸の直進変位を記録することで 直進速度を計測した，さらに，装置全体を地面に対して傾ける ことで出力軸の質量を用いて機構の発生できる推進力を計測し た. Fig. 6 (a) に示すように装置全体を地面に対して $\theta[\mathrm{rad}]$ 傾 けると，摩擦を無視すれば機構が支える出力軸の重さは $m_{\mathrm{s}} \sin \theta$ となる.このため, 角度 $\theta$ を変化させて直進速度が $0[\mathrm{~mm} / \mathrm{s}]$ となる角度を求めれば，機構の発生する推進力と出力軸の質量 の釣り合いから機構の発生推進力 $F_{1}$ が重力加速度 $g$ を用いて 以下のように計算することができる。

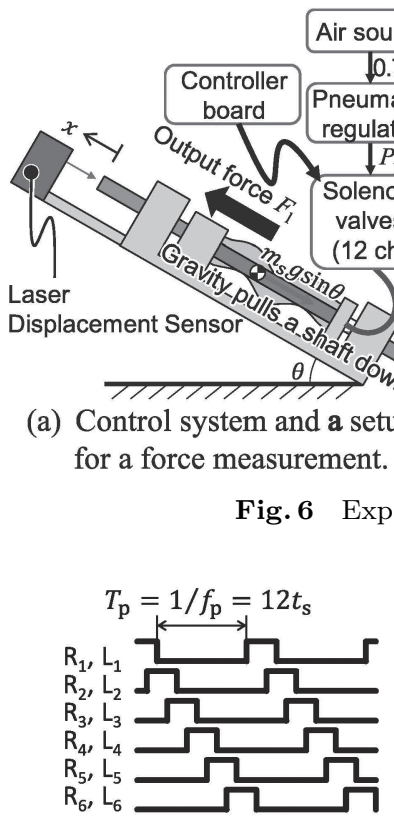

(a) Locomotion pattern

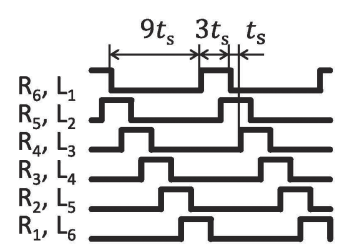

(b) Rotation pattern (b) Setup for a torque measurement.
Output torque $\tau$

Fig. 7 Pressurizing pattern for experiments

$$
F_{1}=m_{\mathrm{s}} g \sin \theta
$$

また，機構の発生するトルクを Fig. 6 (b) に示す実験系で計測 した。機構で糸を巻き上げるとばねが伸び，張力 $T$ が増加す る.このとき, 重量計により張力 $T$ を計測できるため, 機構が 停止した状態での張力 $T$, 出力軸の直径 $d$ を用いて停動トルク $\tau$ が以下のように導出される.

$$
\tau=T \cdot(d / 2)
$$

チューブの印加圧力 $P_{\mathrm{p}}$ や加圧, 減圧の切替周波数 $f_{\mathrm{p}}$ を変化 させながら, 出力軸の動作や推進力, トルクを計測した。

\section{4. 実 験 結 果}

\section{1 駆動周波数と直進速度, 回転速度の関係}

Fig. 7 に示す 2 種類の加圧パターンで機構を加圧し, 試作機 で出力軸を直進方向（Fig. 8 (a)）と，回転方向（Fig. 8 (b)）に 駆動した。直進運動では硬性内視鏡が $2[\mathrm{rpm}]$ で回転しながら $2[\mathrm{~mm} / \mathrm{s}]$ で直進し, 回転運動では硬性内視鏡は $0[\mathrm{~mm} / \mathrm{s}]$ で推 進しながら $32[\mathrm{rpm}]$ で回転し, 直進と回転の 2 自由度の動作 が切り替えられることを確認した。

移動速度を定量的に評価するために試作機を水平に固定して 駆動周波数 $f_{\mathrm{p}}$ と直進速度の関係を計測した. 印加圧力 $P_{\mathrm{p}}$ を $0.2[\mathrm{MPa}]$ として左右両方向で実験した. Fig. 9 (a) に示すよ うに，駆動周波数 $f_{\mathrm{p}}$ と直進速度は線形な関係を示した.

回転動作についても，速度を計測し Fig. 9 (b) に示すように 回転速度と駆動周波数の関係に線形性が確認された.

\section{2 駆動圧力と推進力, トルクの関係}

続いて，試作機が発生可能な直進力を計測するために，試作機 を傾けながら直進速度を計測した. Fig. 10 は駆動圧力 $P_{\mathrm{p}}$ を $0.25[\mathrm{MPa}]$, 駆動周波数 $f_{\mathrm{p}}$ を $2.5[\mathrm{~Hz}]$ として駆動時の直進変 位を計測した結果である. 角度 $\theta$ や変位の定義はFig. 6 に示し
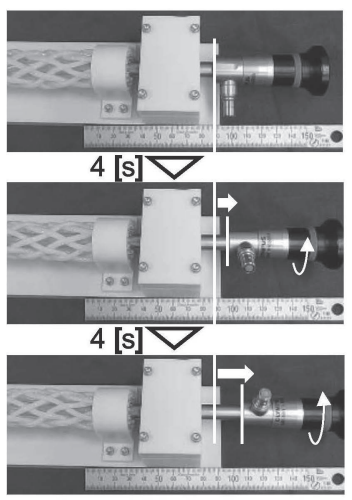

(a) Locomotion

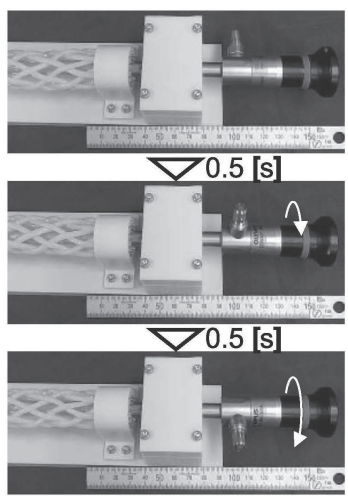

(b) Rotation.
Fig. 8 Motion of a prototype

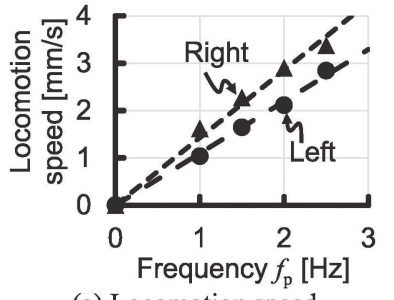

(a) Locomotion speed.

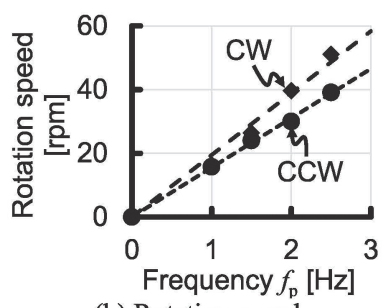

(b) Rotation speed.
Fig. 9 Relationships between speeds and the pressurizing frequencies $f_{\mathrm{p}}\left(P_{\mathrm{p}}=0.2[\mathrm{MPa}]\right)$ 


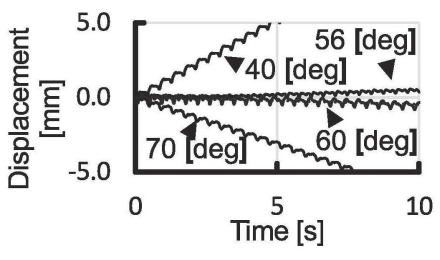

(a) Displacements of an output shaft with some lean angle $\boldsymbol{\theta}$

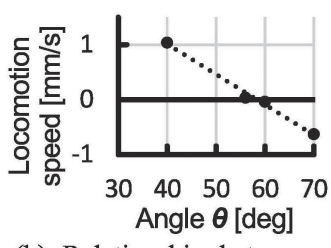

(b) Relationship between a locomotion speed and a lean angle $\boldsymbol{\theta}$

Fig. 10 Experimental results of an output force measurement $\left(P_{\mathrm{p}}=0.25[\mathrm{MPa}], f_{\mathrm{p}}=2.5[\mathrm{~Hz}], m_{\mathrm{s}}=230[\mathrm{~g}]\right)$

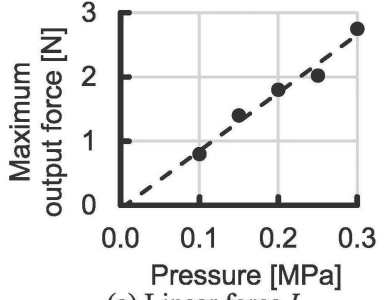

(a) Linear force $I_{0}$

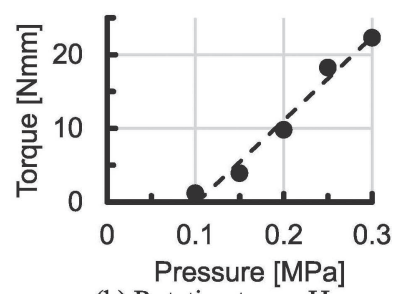

(b) Rotation torqueIJ

Fig. 11 Relationship between forces and a drive pressure $P_{\mathrm{p}}$ $\left(f_{\mathrm{p}}=2.5[\mathrm{~Hz}]\right)$

たものである. Fig. 10 (a) に示すように，角度を $\theta=40$ [deg] とすると出力軸が上昇する一方で, $\theta=70[\mathrm{deg}]$ とすると出 力軸は落下する. 得られた変位を線形近似し直進速度を計算し た. 計算した直進速度と角度 $\theta$ との関係を Fig. 10 (b) に示す. $\theta \simeq 58[\mathrm{deg}]$ で出力軸の質量と試作機の直進力が釣り合うこと が分かった. 安定して出力軸が移動した $0.1[\mathrm{MPa}]$ 以上，接続 配管の耐圧である $0.3[\mathrm{MPa}]$ 以下の範囲内で駆動圧力を変化さ せて同様の実験を行い，駆動圧力と直進力の関係を Fig. 11 (a) のように求めた．計測した範囲では駆動圧力と直進力が線形な 関係を示した．また，人工筋を加圧していない状態で機構を徐々 に傾けて摩擦係数を計測した. $\theta=12[\mathrm{deg}]$ で機構が滑り出し たことから, 直進方向の摩擦係数 $\mu$ は 0.2 であり, 加圧してい ない状態では手で軸を動かすことができる.

同様に，機構の発生するトルクについても各条件で 4 度計測 し, 平均を計算し Fig. 11 (b) の結果を得た. トルクも駆動圧力 と線形な関係であることが確かめられた。

\section{5. 結 論}

本論文では, 複数の空気圧人工筋を編んだ筒状の 1 軸 2 自由 度の直進回転アクチュエータを提案し, 試作機によって実現性 を確認した。提案機構は人工筋の収縮を用いて動作し，人工筋 を加圧, 減圧する順序を工夫することで，出力軸を直進させた り回転させたりできた。また，先行研究におけるチューブの膨 張を用いた機構ではチューブが座屈してしまい，硬性内視鏡の 質量が支えられなかったが，人工筋の収縮を用いることでアク チュエータが座屈しなくなり，2[N] 以上の推進力が発生できる ようになった。本機構は硬性内視鏡 $(170[\mathrm{~g}])$ などの医療機器 を十分駆動でき，手術支援ロボットに応用することでシンプル な構成を実現できる可能性が示唆された。

一方で, 実際に硬性内視鏡を用いる際には接続ケーブル等を接 続するため支えるべき質量が増加する．このため, 出力軸の質 量を支える重力補償を導入し駆動に必要な力を軽減する必要が ある. また, 必要な推進力の削減だけでなく, 発生できる力を増 加も試みたい. 今回の試作機では, 空圧回路を構成するチュー

ブや継手の圧力限界によって, 最大駆動圧力が $0.3[\mathrm{MPa}]$ に制 限されたが空圧回路を見直すことで，より高圧での駆動を実現 し大きな力が発生できると考えている. さらに，同時に 4 本よ りも多くの人工筋を加圧すると機構の内径が小さくなりすぎて 出力軸が引っかかることで推進できなくなる現象が観測された. 今後, 設計を改善してょり多くの人工筋を加圧可能にすること で，より大きな力を出すことのできる機構を目指したい。

また, Fig. 8 (a) に示したように出力軸を直進させる際に出力 軸に回転が生じたり, Fig. 9 に示したように駆動方向によって 速度に差が生じたりした。これは, 組紐状人工筋が厳密に対称 に製造されていないためと考えられる.人間が操作する際には, 操作によって動作の非対称性を解消することができるが, 今後, 直進変位と回転変位を計測してフィードバック制御を導入する ことも検討したい.

謝 辞 本研究はJSPS 科研費 JP17K06253 の助成を受けた.

\section{参 考 文 献}

[1] H. Kimura, M. Kataoka, T. Higashi and N. Inou: "Development of flexible ciliary actuators and their application to mobile robots," J. Aero Aqua Bio-mechanisms, vol.4, no.1, pp.71-77, 2015.

[ 2 ] B. Chen, Y. Zhu, J. Zhao and H. Cai: "Design of a prototype of an adaptive soft robot based on ferrofluid," IEEE Int. Conf. Robot. Biomimetics (ROBIO), pp.511-516, 2015.

[3] J.R. Amend, E. Brown, N. Rodenberg, H.M. Jaeger and H. Lipson: "A positive pressure universal gripper based on the jamming of granular material," IEEE Trans. Robot., vol.28, no.2, pp.341-350, 2012.

[4] J. Krahn, F. Fabbro and C. Menon: "A Soft-Touch Gripper for Grasping Delicate Objects," IEEE/ASME Trans. Mechatronics, vol.22, no.3, pp.1276-1286, 2017.

[5] W. Crooks, S. Rozen-Levy, B. Trimmer, C. Rogers and W. Messner: "Passive gripper inspired by Manduca sexta and the Fin Ray ${ }^{\circledR}$ Effect," Int. J. Adv. Robot. Syst., vol.14, no.4, pp.17, 2017.

[6] I.N.A.M. Nordin, A.A.M. Faudzi, M.Z. Kamarudin, D.E.O. Dewi, T. Rehman and M.R.M. Razif: "Grip force measurement of soft-actuated finger exoskeleton," J. Teknol., vol.78, no.6-13, pp.25-30, 2016.

[7] H. Zhao, R. Huang and R.F. Shepherd: "Curvature control of soft orthotics via low cost solid-state optics," Proc. IEEE Int. Conf. Robot. Autom. (ICRA), pp.4008-4013, 2016.

[ 8 ] Z. Wang, M. Zhu, S. Kawamura and S. Hirai: "Comparison of different soft grippers for lunch box packaging," Robot. Biomimetics, vol.4, no.1, p.10, 2017.

[ 9 ] M. Vázquez, E. Brockmeyer, R. Desai and C. Harrison: "3D Printing Pneumatic Device Controls with Variable Activation Force Capabilities," Proc. 33rd Ann. ACM Conf. Human Factors Computing Syst., pp.1295-1304, 2015.

[10] S.J. Kim and S.C. Lee: "Technical and instrumental prerequisites for single-port laparoscopic solo surgery: State of art," World J. Gastroenterol., vol.21, no.15, pp.4440-4446, 2015.

[11] A. Girard, J.L. Bigué, B.M. O'Brien, T.A. Gisby, I.A. Anderson and J. Plante: "Soft two-degree-of-freedom dielectric elastomer position sensor exhibiting linear behavior," IEEE/ASME Trans. Mechatronics, vol.20, no.1, pp.105-114, 2015.

[12] 寺島光一, 塚越秀行： “単線入力で蠕動運動を生成する柔軟線状アク チュエータの提案”, ロボティクス・メカトロニクス講演会講演概要 集, 2P1-04b7, 2016.

[13] K. Ozaki, S. Wakimoto, K. Suzumori and Y. Yamamoto: "Novel design of rubber tube actuator improving mountability and drivability for assisting colonosocope insertion," Proc. IEEE Int. Conf. Robot. Autom. (ICRA), pp.3263-3268, 2011.

[14] J.M. Sackier and Y. Wang: "Robotically assisted laparoscopic surgery - From concept to development," Surg. Endosc., vol.8, no.1, pp.63-66, 1994.

[15] X. Sun, Y. He, Y. Hu, P. Zhang, H. Zhang and J. Zhang: "De- 
sign of a robotic endoscope holder for sinus surgery," 2015 IEEE Int. Conf. on Robotics and Biomimetics (ROBIO), pp.391-396, 2015.

[16] M.J.H. Lum, D. Trimble, J. Rosen, K. Fodero, H. H. King, G. Sankaranarayanan, J. Dosher, R. Leuschke, B. MartinAnderson, M.N. Sinanan and B. Hannaford: "Multidisciplinary Approach for Developing a New Minimally Invasive Surgical Robotic System," 2006 First IEEE/RAS-EMBS Int. Conf. on Biomedical Robotics and Biomechatronics (BioRob), pp.841846, 2006.

[17] A. Bruyas, F. Geiskopf and P. Renaud: "Toward unibody robotic structures with integrated functions using multimaterial additive manufacturing: Case study of an MRI-compatible interventional device," 2015 IEEE/RSJ International Conference on Intelligent Robots and Sytems (IROS), pp.1744-1750, 2015.

[18] P. Li, H.M. Yip, D. Navarro-Alarcon, Y. Liu, C.F.M. Tong and I. Leung: "Development of a robotic endoscope holder for nasal surgery," 2013 IEEE International Conference on Information and Automation (ICIA), pp.1194-1199, 2013

[19] K. Tadano, K. Kawashima, K. Kojima and N. Tanaka: "Development of a Pneumatic Surgical Manipulator IBIS IV," J. Robot. Mechatronics, vol.22, no.2, pp.179-180, 2010.

[20] A.J. Madhani, G. Niemeyer and J.K. Salisbury: "The Black Falcon: a teleoperated surgical instrument for minimally invasive surgery," 1998 IEEE/RSJ Int. Conf. on Intelligent Robots and Systems (IROS), vol.2, pp.936-944, 1998.

[21] H. Li, K. Kawashima, K. Tadano, S. Ganguly and S. Nakano: "Achieving haptic perception in forceps manipulator using pneumatic artificial muscle," IEEE/ASME Trans. Mechatronics, vol.18, no.1, pp.74-85, 2013.

[22] K.J. Meessen, J.J.H. Paulides and E.A. Lomonova: "Analysis and design considerations of a 2-DoF rotary-linear actuator," 2011 IEEE International Electric Machines \& Drives Conference (IEMDC), pp.336-341, 2011.

[23] K. Taniguchi, A. Nishikawa, F. Miyazaki, T. Kobayashi, K. Kazuhara, T. Ichihara, M. Sekimoto, S. Takiguchi and M. Monden: "Development of a safe disposable laparoscope manipulator using hydraulic actuators," 2007 IEEE Int. Conf. on Robotics and Biomimetics (ROBIO), pp.601-606, 2007.

[24] K. Guo, S. Fang, H. Lin, Y. Huang, Y. Zhang and H. Yang: "A Linear-Rotary Permanent Magnet Actuator with Independent Magnetic Circuit Structure," IEEE Trans. Appl. Supercond., vol.26, no.7, pp.1-6, 2016

[25] T. Mashimo, S. Toyama and H. Matsuda: "Development of rotary-linear piezoelectric actuator for MRI compatible manipulator," 2008 IEEE/RSJ Int. Conf. on Intelligent Robots and Systems (IROS), pp.113-118, 2008.

[26] A. Kanada, T. Mashimo and K. Terashima: "Study of rotarylinear ultrasonic motor output shafts," Int. J. Autom. Technol., vol.10, no.4, pp.549-556, 2016.

[27] 辻賢一郎, 高山俊男: “編みチューブ式 1 軸 2 自由度空圧駆動アク チュエータの開発”, 第 34 回日本ロボット学会学術講演会予稿集 DVD-ROM, 1W1-07, 2016.

[28] T. Takayama, H. Takeshima, T. Hori and T. Omata: "A Twisted Bundled Tube Locomotive Device Proposed for In-Pipe Mobile Robot," IEEE/ASME Trans. Mechatronics, vol.20, no.6, pp.2915-2923, 2015.

[29] H. Takeshima and T. Takayama: "Six-braided tube in-pipe locomotive device," 2015 IEEE/RSJ Int. Conf. Intell. Robot. Syst. (IROS), pp.1125-1130, 2015.

[30] 種田宇志, 高山俊男：“平面編みチューブ式ソフトロボットの開発”, 第 35 回日本ロボット学会学術講演会予稿集 DVD-ROM, 1J2-02, 2017.

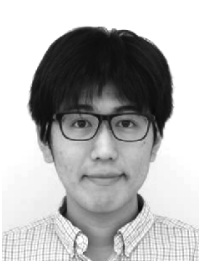

竹島啓純 (Hirozumi Takeshima)

2014 年東京工業大学工学部卒業. 2016 年同大学大 学院総合理工学研究科メカノマイクロ工学専攻博 士前期課程修了. 2019 年同大学工学院機械系機械 コース博士後期課程を修了.

（日本ロボット学会正会員）

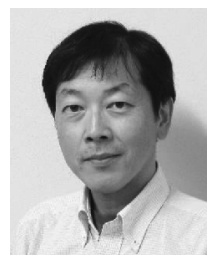

高山俊男 (Toshio Takayama)

1998 年東京工業大学機械宇宙学科卒業, 2004 年同 大学機械宇宙システム専攻博士課程修了後, 同大学 大学院総合理工学研究科メカノマイクロ工学専攻助 手, 講師, 准教授を経て, 2017 年大阪大学准教授, 2019 年より東京工業大学工学院准教授。移動ロボッ ト, 医療ロボット, マイクロ流体デバイスを研究テー マとする. 日本ロボット学会第 20 回, 23 回論文賞, 2017IEEE CBS Best Conference PaperAward, 2018 年度機械学会ロボテイクスメ カトロニクス部門欧文誌表彰等を受賞. （日本ロボット学会正会員）

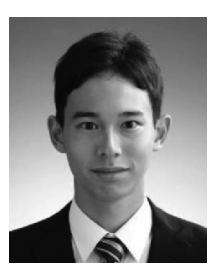

辻賢一郎（Kenichirou Tsuji）

2016 年東京工業大学工学部卒業. 2018 年同大学工 学院機械系ライフエンジニアリングコース博士前期 課程修了. 